\title{
Odysseus Reborn: Parallelism between Odysseus and The Postmodern Man
}

\author{
Abdullah Parwaiz \\ B.A(Hons.) English Literature \\ Department of English \\ Aligarh Muslim University \\ Aligarh, Uttar Pradesh, India \\ abdullahparwaiz54@gmail.com
}

Abstract

The mythical character of Odysseus has been a recurring figure since his first introductions, in the Great Greek writer, Homer's works around 700 BCE, in the, 'Illiad', and, 'Odyssey'. He has been invoked over the ages to suit the means of the said eras, trans-morphing the character of the Classical Greek Hero to meet the desired ends of the poets, authors and periods. The aim of the paper is to deconstruct the works where he has been mentioned and thus in turn construct the character itself. This will be done through the famous works he has been mentioned in, such as Virgil's 'Aeneid', Dante's 'Inferno', Horkheimer and Adorno's 'Dialectic of the Enlightenment'. In doing so, the paper shall establish the grounds for Odysseus to come out as a character that suits all ages for a good reason. Furthermore, a Psychoanalytical analysis and study shall establish his relevance and stand in the Postmodern age that we live in, which shall aim to decentralise popular notions, moving away from the modernist experimentation towards the postmodern appreciation of the classical character as one, who at the true core had been formed with such intricacy that writers have been forced to adapt him in their works, time and again. 
Keywords: Odysseus, Postmodern, Homer, Odyssey, psychoanalysis, PTSD, Hemmingway

Methodology

The method used in the paper is influenced majorly by two writers and a recent research paper, one of the late modern era and the other of the postmodern era. The former is the work of two German Philosophers, Max Horkheimer and Theodore Adorno, during their exile in New York, from Nazi Germany, in 1940s, who wrote, 'Dialectic of Enlightenment' and the latter being, Terance P. Logan, a dramatist who wrote, in 1962, 'The Characterization of Ulysses in Homer, Virgil and Dante: A Study in Sources and Analogues'. The research paper that serves as a reference to establish the characters relevance through a Psychoanalytical approach is, Christopher D. Martin's , 'Ernest Hemingway: A Psychological Autopsy of a Suicide'.

Horkheimer and Adorno served as a major influence in the methodology, by casting the relevance of the character in modern times as a figure of Enlightenment from the Classical age. Terance P. Logan's work helped in laying the grounds for comparing the character over a span of 2000 years through three major works up to 1300 A.D., which had majorly shaped the character of Odysseus. Finally, the paper by Christopher D. Martin lays out the psychological study of an important postmodern figure, helping us to compare him to the psychology of Odysseus.

The method is that of Post-structural analysis meant to deconstruct the works where the character of Odysseus has been mentioned, which in turn aims to construct the character itself through the method of Psychoanalytical approach, showcasing his relevance in the postmodern times. 


\section{The Classical Greek Hero: Odysseus}

Odysseus is the protagonist and Greek hero of the renowned epic written around 700

BCE, by Homer, which recounts the tale of Odysseus's journey back home, after the events of the 'Illiad', another Homeric poem telling us of the revered tale of the Trojan War. While 'Illiad' gives us some account of Odysseus and his ways, it is in 'the Odyssey', that we see him in his crudest form. The importance of the book is such that it will lay down the foundations of the character, which will resonate through ages to come, moulding the Greek hero into various renditions.

The trueness of the character can be recounted through the various events that take place in the 10 years that take him to reach home, a journey that should have, in reality, taken merely a period of 14 days.

For our purposes, to establish the originality of the character, we shall discuss one famous event from the epic. This will, in turn, be used to correlate with the next part of this paper, such as done by the playwright, Terence P. Logan, in his paper, 'The Characterization of Ulysses in Homer, Virgil and Dante: A Study in Sources and Analogues', to establish the connection between the Heroic Odysseus and the Vile Ulysses.

In Book 9, when on the island of 'Scheria', after it is revealed to King Alcinous that the figure they have been harbouring is indeed, after all, Odysseus himself (Homer 10-21); it is demanded by the king to tell him of his adventures if he hopes to get their much-sought help. So Odysseus recalls that after the events of the Trojan War, as they left for Ithaca, the crewmen in their greed took one more stoppage to pillage a land (50-70). After they are chased back by its inhabitants, as the ship sailed, strong winds threw them off course, to the island of the Lotus-eaters(92-95). Here, in the account of what happens between the Cyclops Polyphemus and Odysseus, do we see the courageous, bold, witty and clever hero of the epic, take a stance. 
So, you ask me the name I'm known by, Cyclops?

I will tell you. But you must give me a guest-gift as you've promised. Nobody-that's my name. Nobody - so my mother and father call me, all my friends/ (Homer 410)

After Polyphemus captures them, driving them into his cave here, Odysseus tells his name as, 'Udeius', similar to his real name, which translates to, 'Nothing'. And so, when the Cyclops is stabbed in the eye by Odysseus and his crew, the cries of Polyphemus saying, 'Nobody is attacking me', saving them from any trouble with other Cyclops that might have come to aid.

I called back with another burst of anger, 'Cyclops - if any man on the face of the earth should ask you who blinded you, shamed you so-say Odysseus, raider of cities, he gouged out your eye,

Laertes' son who makes his home in Ithaca!' (Homer 560)

But as they are leaving the island, Odysseus shouts back saying, that if anyone ever asks, tell them that it was Odysseus who stabbed your eye. This in turn angers the God Poseidon (father of Polyphemus), and this act of foolishness costs him years of suffering, hindering his travels back home.

In doing so, we see the many heroic talents of Odysseus play out but also witness his hamartia, which is that of 'Hubris', the personality trait of an inflated ego, alongside arrogance.

Through this one account, having established the persona of Odysseus through Homer's epic, we will now move on to another great epic written by the poet, Virgil, who in his poem, 'Aeneid', portrays Odysseus quite differently than what we till now see him as. 2. The Heroic Odysseus to The Vile Ulysses

This part of the paper shall focus on how the famous Greek hero is portrayed as vile and cruel. A portrayal that was constructed by Virgil, the great Roman poet who wrote, 
'Aeneid', in around 30 BCE. And a portrayal that was seen in another great epic by the Italian poet, Dante Aligheri in his work, 'Inferno', written around 1308, A.D. This portion shall outline the historical tension and background that served to such morphing.

In $30 \mathrm{BCE}$, the Roman Empire was going through great political rifts and battles to establish control over a great part of the known world. The Romans considered themselves to be the descendants of the Trojan warriors, and thus we see the main grounds of why the poet directed such hatred towards the Greeks, who pillaged Troy, wreaked incalculable havoc and laid ruin to the great city. Odysseus is the key strategist in the Iliad, responsible for the winning strategy of the infamous Trojan Horse and for recruiting Achilles, fulfilling the prophecy that the Greeks shall emerge victorious in the Trojan War.

Throughout the work, we see great influence of the Greek writer Homer in the Aeneid, where the first half deals with the travels of Aeneus, just like the travels of Odysseus in the Odyssey, and the rest of the part dealing with war, just as seen in the 'Illiad'. Though Virgil doesn't attribute the influences directly to Homer, it is quite evident throughout his epic. This is a key point to be noted as we see the constructivism that comes with Literature, that crosses boundaries to work on characters and forms, borrowing from famous writers, learning from their contribution to Arts, rather than just dwindling on ways to despise.

Instead of dwelling on the discussion of the story of the Aeneid and its comparison to Homer's works, we shall see how Odysseus is transformed in the Aeneid.

The first fact comes from the historical point of view. The Aeneid was written at a time when Rome was still recovering from the repercussions of the war with Greece. And tension was brewing between the Eastern part of the Roman Empire, controlled by Mark Antony alongside Cleopatra, and the Western part under the rule of the great Octavian, later known as Augustus Caesar. The Romans felt that this sporadic ball of events had originally been set rolling by the Greeks. This internal conflict came to a resolution, after the war that 
took place in the bay of Actium under the rule of Augustus with the help of the master strategist Marcus Agrippa. His victory was followed by Mark Antony and Cleopatra committing suicide, leading Octavian to rule over the whole Roman Empire, bringing in an era of much sought peace. And thus to commemorate the Brilliant Octavian and the prosperity of Rome brought under him, Virgil writes Aeneid, that states the tale of the founder of Rome, and so it becomes quite clear, that when viewed from a different perspective, the great Greek heroes whom the Romans held responsible for the chain of events shall succumb to villainous traits as perceived by the Romans.

The epic 'Aeneid' starts in Medias res, as we see Aeneus escaping from the clutches of the Greek Invaders, along with his son and father. What follows in the first half, is the story of his travels, searching the land of Italy to lay down its foundations and thus following the path to fulfilling his prophecy of being the founder of the Roman Empire. The villainy of Odysseus is quite apparent as Aeneus flees the ruins of Troy to escape his clutches. As the Queen Goddess Juno is hell-bent on hindering the plans of Aeneus, so that the kingdom of Carthage rules the world instead of the future Roman empire. As of now, Dido is the ruler of Carthage, and by the end of Book one, through a meddling act by Juno, Aeneus lands at the city of Carthage. And thus, the tale at the request of Dido, starts to unravel, and at the same time for our purposes, deconstructs the character of the classical Greek hero, Odysseus.

The first mention of Odysseus is seen in the first stanza of Book 2 of Aeneid, as, "iron-hearted Ulysses" (Virgil 5-10), (note:- Ulysses is the Latin name for, 'Odysseus'), implying on how Odysseus brought havoc and hell upon Aneus's beloved city of Troy. Again Book 2 invokes his name, in context to the warning that Aeneus gives to Troy's inhabitants, warning them of the Trojan force and the cunning deception of Ulysses (40-45). Further on, Ulysses is dubbed as 'vicious', when he threatened and killed the seer who knew through a prophecy, the plan that eventually lead Troy to its demise, thus preventing him 
from impeding their plans (120-125). Later, he is referred to as 'the mastermind of crime', in reference to him stealing the idol of 'Pallas Athene' from the hallowed shrine during the pillaging of Troy (160-165). Then when Aeneus tells the tale of how the slaughter began, he refers to Ulysses as 'ruthless' (260-265). In Book 3, as Aeneus speaks of his travels at sea, he mentions Ulysses as 'savage', while passing by the island of Ithaca, of which Ulysses was King. On seeing the various ways in which Ulysses is invoked and his character bashed, the final blow to his character comes down to a particular incident from Book 3, when Aeneus finds himself on a land near Mt.Etna (610-615), home to the Cyclops Polyphemus (refer to part one of paper). Here we see Virgil invoke the character of 'Achaemenides', one who is never heard of in Homer's works, and this is done precisely to harm the Heroic status of Odysseus. For in the Aeneid, Achaemenides is shown as a character left to rot with Polyphemus, by Ulysses, and this gives Virgil the opportunity to bring grandeur to the character of Aeneus, the man who saves a Greek, thus showing that he is ever forgiving and pious.

Thus the classical Greek hero is transmogrified into a vile, vicious, ruthless and savage, an all-round heathen character, in contrast to everything Aeneus stands for, the best of the Roman men, who is good and pious, brilliant and virtuous, a man of principle, smart not cunning, heedful to the Gods unlike Odysseus.

The above reading is to justify why Virgil portrays Odysseus as such, and at the same time use literary and historical facts to bring out the contrast between the Hero and the Villain, Odysseus. In totality, Odysseus and Ulysses are both one yet different at the same time- two sides of the same coin or two different coins meant to serve different purposes.

3. Odysseus and Christianity: Dante's Inferno

Dante Alighieri was an Italian poet who lived towards the end of the 13th century, he is considered to be the flag bearer of the Italian Renaissance, his most famous work is 
considered to be the 'Divine Comedy', which he wrote after being exiled from Florence in 1301. It was completed in 1320, a year before the poet's death. For our purposes, we shall see how Ulysses has been treated in the Divine Comedy, where he has been mentioned in the first part, that is the 'Inferno', and see whether the treatment was out of some biases and unjust or whether Ulysses got the end that he deserved.

First, to understand what brought on such inspiration to Dante, we will look at the historical background that leads to the Divine Comedy. The Italian peninsula was going through a great political rift that heavily unbalanced the workings of the city of Florence. During Dante's time, Italy was not unified, and was going through a power struggle between the Guelfs and Ghibellines. The former supported the Pope while the latter supported the emperor. The battle of Colle di Val d'Elsa in1269 put Florence under Guelf control. But after this, even the Guelfs were divided into two sects, the white Guelfs and the Black Guelfs. The Black Guelfs were unmoving in their ideology and resented artists and poets.Later,under the control of the notorious Pope Boniface VIII, the black Guelfs emerged as the ones to control Florence completely, exiling Dante Aligheri in 1301. The Divine Comedy, as brilliant a piece of literature, is also a piece written out of resentment due to his exile, this is further evident when on reading the Inferno, we see Dante place many politicians in the circles of hell and even reserving a spot for Pope Boniface VIII, in the 8th circle (Virgil XIX, 49-60).

To some account, by the decree of Dante, these figures might have gotten what they deserved; but does Ulysses, who suffers in the eight circle of hell, also deserve so?

On reading the Divine Comedy, two facts emerge out effortlessly- the first that Dante wrote this piece as a gift to his love interest, Beatrice Portinari, after her death in 1290 . The journey through hell and purgatory is to ultimately meet her in heaven, and the Divine Comedy is the flicker of hope that he clings on to, throughout his isolated exile. But since heaven is for the worthy, Dante must first travel through the depths of hell and then climb the 
mountain of purgatory to meet her in heaven. The second fact that emerges, is that in order to aid his travels, Beatrice sends the figure that Dante heavily idolizes, that being Virgil, the famous Roman poet that we discussed in the previous portion of the paper.

Since Dante places himself as the descendants of the Romans, it shows quite clearly the biasness that he might hold against the Greeks who ravaged the city of Troy. In Canto 26 of the Inferno, we see Ulysses burning in a flame entwined with Diomedes, (for their sacking of Troy through the unfair and vile strategy of the Trojan horse), out of curiosity Dante asks Virgil to ask them why they burn in hell. Ulysses then recounts his last journey that led to his death and finally to hell (Virgil 90-142). Two profound observations derived from the aforementioned instance are- Dante tries to portray Ulysses as a selfish man who doesn't care for his son, wife, and father, abandoning them on the island of Ithaca to seek the edge of the earth out of some petty self-centered desire (96-99). But in Homer's Odyssey, this classical Greek hero had earlier spent 10 years tirelessly to get back home, and then had fought against his wife's suitors, portraying him as otherwise. Secondly, considering that Ulysses did leave, it would have been for a good reason. On reading the Canto closely, we see that Ulysses hoped to seek the edge of the world. As he reached a mountain that seemed to him to be the final destination, just as he is close by, a harsh wind sent by the Christian God, destroys his ship, killing him and his crew (135-142). Now, considering that Ulysses somehow lived through the pagan age into the Christian world, what contradicts the text is that, if Ulysses wanted to find the edge of the world and the mountain was the destination he sought, could it be that it was the mountain of purgatory that he wanted to climb as he approached the end of his life, in the hope to seek salvation for himself and for the whole of Ithaca.

Another contradiction that surfaces is through the doctrine of Bible itself. While the Divine Comedy does lay out an incredible description of the life after death, in the biasness that Dante himself holds, playing God and sentencing characters such as Ulysses to hell, the 
teachings of Jesus Christ in the Bible are contradicted in the process. Considering that Ulysses sought salvation in the end; the doctrine that says, 'My command is this: Love each other as I have loved you.' (John, 15:12); or "But to you who are listening I say: Love your enemies, do good to those who hate you." (Luke, 6:27). Furthermore, when the Christian God tells his believers that, "for all have sinned and fall short of the glory of God," (Romans 3:23), how could it be that He would be cruel towards a man who wanted redemption. How could it be that a man who had suffered for so long, defying his own Gods, does not have any place in the Kingdom of Heaven or at least on the mountain of purgatory, like Virgil.

And thus, on looking at the character and transformation of Odysseus into the vile Ulysses, him being put to trial by Virgil and eventually being sentenced to hell by Dante, a lot of key aspects become apparent. From the character being morphed heavily in the 2000 years up to the time when the Inferno had been written, Odysseus had been shaped according to the ever changing ideologies and out of biases and maybe even resentment. This portion of the paper not only deconstructs the works but in the justification through facts, has successfully redeemed the character to his true original form.

\section{The Modern Ulysses}

This portion of the paper shall shift the narrative from defaming the name of Odysseus, that had been done over the course of 2,000 years, to one where the age-old question of Enlightenment comes to a halt at the end of the Modern era, with a book that tried to invoke Ulysses as a Modernist symbol of Enlightenment, debunking the many ideas that went on over the course of two centuries. For our purposes, we will view Ulysses through a Modernist perspective, and observe the classical hero's relevance even after 2,700 years of first being mentioned.

Max Horkheimer and Theodore Adorno's book , 'Dialectic of Enlightenment', was published in 1944. Horkheimer and Adorno were two Jewish German philosophers living in 
exile in New York, USAduring the reign of Hitler. The book is based on a conversation they had, addressing one major question, 'Why has or had the Enlightenment, which sought to release man from chains into a freedom of thought gone so terribly wrong?'

The book begins with the classic notion of Enlightenment, given by one of the first Enlightenment figures Emanuel Kant in his essay, 'Answering The Question: What is Enlightenment?', which begins by saying,

"Enlightenment is man's release from his self-incurred tutelage....courage to use it without direction from another. Sapere Aude! 'Have courage to use your own reason!'- that is the motto of enlightenment."(Kant 11-12)

And thus it was seen as something which was to lift man from myth and religion into the age of reason and intellect.

Max and Adorno in their book, speak of enlightenment as a mechanism that was intended to be an instrument in enhancing the life of humans with the modern man as its main subject.

They cite the example of Odysseus from Homer's Odyssey in chapter two of their book seeing Odysseus as a symbol of the modern man. (Horkheimer and Adorno 1)

Y. Sherratt in his treatise 'Adorno and Horkheimer's Concept Of Enlightenment' on Max and Adorno's book examines the connections made by them between the modern man and the classical Greek hero Odysseus.

"Odysseus, (Adorno and Horkheimer believe), embodies the most crucial feature of the enlightenment Subject. His behaviour is 'goal orientated'. That is to say, Odysseus guards himself against spontaneity and does not merely venture into the world with an openness to contingency... Odysseus has a goal and in this respect is prototypically enlightened" (Sherratt 534). 
Max and Adorno in their book, compare the character of Odysseus to the Subject of Enlightenment.

"From the formalism of mythical names and statures, which, indifferent like nature, seek to rule over human beings and history, emerges nationalism, the prototype of bourgeois thinking. Self-preserving guile lives on the argument between word and thing. Odysseus's two contradictory actions in his meeting with Polyphemus, his obedience to his name and his repudiation of it, are really the same thing. He declares allegiance to himself by disowning himself as Nobody; he saves his life by making himself disappear. This adaptation to death through language contains the schema of modern mathematics" (Max and Adorno, 48).

This basic gesture of self-rejection in the name of self-reclamation, Adorno labels as cunning (Max and Adorno 39).

Odysseus throughout his journey is seen running recklessly towards danger, as an unhealthy way of going about the act of self-preservation, a key trait of a Bourgeois individual (Max and Adorno 24). Next, he is seen outwitting mythic forces and ever trying to be at loggerheads with the Gods, whom instead of offering sacrifice to, he cheats. Max and Adorno go on to say how the deals he offers are a form of deception, fooling the Gods such as Poseidon. In the sacrifice of selfish desires, by not accepting tempting offers of the Gods, Odysseus promotes selfhood but at the same time becomes a victim, as in the pursuit of upholding selflessness; he has now become a victim of sacrifice.

From the above account, we see how Odysseus in his pursuit of self-preservation renounces his own identity, a self-reclamation that works as a paradoxical endeavour. During his voyage, he starts to lose himself, the changing behavioural aspect that can be seen due to the aftermath of war, and even after his return to Ithaca, the trauma of it all still has a detrimental effect on him. This is reflective of the modern war veteran when he has returned 
to the comfort of the home. The war veteran tries to repress the mentally scarring memories of war, but it only leads to more internal conflict. And this seemingly progressive behaviour of trying to renounce the past, in actuality paves the path for irresistible regression (Max and Adorno 28).

And thus we symbolise the mixed character of the hero Odysseus and the cunning Ulysses, in the Modern times, as one who had in him the potential of an Enlightenment figure, long before anyone dared to question that which know to be supernatural, mythic or irrational. The superfluous carving and morphing of the character makes him such that we try to find Ulysses in our everyday lives, as the, "really real", around us, and even in us, which the modernist writers so thoroughly aimed to find.

5. The Postmodern Odysseus

This portion of the paper brings us to the final part, one that had begun by stringing the character of Odysseus through the works where he had been mentioned over the ages, to now finally constructing a bridge through two Nobel Laureates; one whose Postmodern poem shall be discussed as it invokes the name of Odysseus and the other being a renowned Postmodern figure; in order to draw comparisons through the method of Post-structural deconstruction along with Psychoanalytical approach, to showcase how Odysse us stands as a relevant figure more than ever, even in our Postmodern times.

The postmodern poem that we will be referring to for our purposes is, 'Odysseus to Telemachus', written by the eccentric, bold, witty postmodern Nobel Laureate (Nobel Prize in Literature, 1987) Joseph Brodsky (1940-1996) in his book ‘A Part Of Speech’. Brodsky lived a life of peril as he was exiled from the Soviet Union brought under a trial for, 'social parasitism'. But the irony lies in the very trial that accused him of being a liability to the community as it gained him praise in the West, when the transcript of the trial was smuggled and published, which showed his brilliance as an eloquent idealist, and his courage in the way 
he answered the prosecutors. He faced further trauma when he was forced to spend 5 years in the Arctic labour camp, ultimately being saved by the help of poet W.H. Auden, immigrating to Michigan in 1972. When we look closely at the life of the poet and of Odysseus (as discussed through the first three portions of the paper), through the poem at hand, a Psychoanalytical approach reveals the sign of Post Traumatic Syndrome or PTSD, a syndrome that evolved from the term, "shell shock", as it originates from the study of trauma that war veterans face, The American Psychiatric Association defines PTSD as, "a mental disorder that can develop after a person is exposed to a traumatic event such as sexual assault, warfare, traffic collisions, child abuse or other threats on a person's life" (Diagnostic and Statistical Manual of Mental Disorders, 271-280). This results in alterations in how a person thinks and feels and an increase in the flight or fight response (271-280). The poem superfluously guises Joseph Brodsky as Odysseus, a man who has lost all hope, a victim of war and trauma, evident in the lines

"Grow up, then, my Telemachus, grow strong.

Only the gods know if we'll see each other

again." (Brodsky, lines 20-22)

This is a reflection of the poet's own trauma and the feeling of relatability he shares with the Greek mythical hero. The poem is ladled with abhorrence for the island (of Aeaea) which is similar to the way Brodsky felt for the Arctic labour camp. The poem also conveys a strong feeling of longing and nostalgia, the way Odysseus must have felt for Ithaca, and the way Brodsky felt for his hometown in Russia. The foundational aspect of the poem is the most important factor that depicts The Greek Hero's hopelessness, as the poem is a final letter to his son Telemachus, and like Brodsky's self elegy. It can be contrasted with letters of war veterans of the postmodern era; for the tone reveals no optimism, and only remembrance in such a way that he means to bid him goodbye. 
To depict Odysseus as the postmodern war hero and veteran, we shall draw comparisons to the iconic Postmodern war figure and author, Ernest Hemmingway, who lived from 1899-1961, and won the Nobel Prize in Literature in 1954. These comparisons shall at last reveal the place Odysseus holds in our postmodern era.

Hemmingway reported for 'The Kansas City Star' newspaper for a few months after $10^{\text {th }}$ grade (1917). He then left for the Italian Front and enrolled himself in the World War 1. His book 'A Farewell to Arms', published in 1929, gives an outlining account of his experience in the World War I, through the character of Henry. In it he narrates, what can be seen as Hemmingway's perspective on trauma,

"If people bring so much courage to this world the world has to kill them, so of course it kills them. The world breaks everyone and afterwards many are strong at the broken places. But those that will not break, it kills. It kills the good and the very gentle and the very brave impatiently face the ongoing situations" (Hemmingway 258).

This gives us an in-depth analysis of how a man of war would view trauma to be something that breaks a person to the core, and if war doesn't take their life, many end up doing it themselves. Furthermore, we see symptoms of the survivors' guilt syndrome in war veterans. It is defined in 'The Survivor Syndrome: Further Observations And Dimensions' as the multidimensional consequences of shattering experiences and the traumatisation sustained by the victims, of severe magnitude and duration as to produce a clinical entity called survivor syndrome (Niederland 413). Odysseus knows full well how he had played a major part in winning the war that led to the absolute destruction of Troy and the loss of many great warriors. Another major factor that he suffers from the syndrome lies in the fact, that in his travels back to Ithaca, described in Book 12 of The Odyssey, he lost many a crew members, in the events such as when Zeus strikes down his ship (Homer 544-549) and since the Greek hero survives it all, it undoubtedly instils in him the survivors syndrome. 
Let us take into consideration the major instances in the case of Odysseus to see whether trauma could have been induced in his life. The death of a parent is a major aspect that can cause PTSD and other traumas in a person's life. In the case of Odysseus, when he meets his mother in the Underworld in Book 11, he is surprised to find her there. On conversing with her, the heartbreaking revelation is brought to Odysseus, that his mother took her life, as she could not bear the longing to see her son anymore (Homer 230-250). The second instance that we shall consider is when Odysseus encounters the song of the Sirens; when viewed from a psychoanalytical perspective, we see how the instance reveals repressed suicidal tendencies of Odysseus. As established by the poem, the war of the mind had already begun for Odysseus; the letter that Odysseus writes is from his time at the island of Aeaea, which belongs to Circe where he spends about a year, and the song of the Sirens he encounters just thereafter. In Book 12, even though having been warned by Circe about the maddening powers of the Siren's song (Homer 44), Odysseus is seen defying the warnings as he makes his crewmen cover their ears with beeswax, but himself chooses to listen to the song, having made them tie him to the mast of the ship (210-220). Such measures aren't ordinary and Odysseus in the end, is human, and so it isn't surprising to witness him take up such pursuits, of inflicting self-harm, a mechanism seen as defensive in many neurotic patients. Furthermore, even though the life of a war hero and veteran is celebrated by the masses once they return, for the hero himself, apart from the perils of his own mind, bureaucratic troubles rise up as well. A book by Jonathan Shay, by the name 'Odysseus in America: Combat Trauma and the Trials of homecoming', states this well by comparing the instance of the Cyclops Polyphemus and Odysseus to Vietnam war veterans,

"Odysseus has no hope against the Cyclops [the one-eyed giant cannibal] in a force-on-force match up. This is the way some veterans I work with feel when they face the government. They see themselves as powerless, liable to be eaten alive. Cunning, they 
believe, is their only defense. Like any one-eyed creature, government bureaucracies lack depth perception. They tend to see only the one thing they were set up for, and are blind to how things interconnect" (Shay 47).

This brings out the final problem of the war hero, and Odysseus isn't above it as well, for the old Odysseus, though king, would have lost the way of ruling in the 20 years he had been away and the troubles of the island and the court shall only worsen matters of his own mind, as it does for all who go to war, the troubles of normal life become absurd to them.

In the postmodern veteran such as Hemmingway, we see a life that is reflective of the traumas that he has endured and his habits and tendencies that only amplified the mental disorders more severely. For a brief look into the traumatic mind of Hemmingway, we will be referring to the paper by Christopher D. Martin, '’Ernest Hemingway: A Psychological Autopsy of a Suicide'. First, we see the same trauma that Odysseus faced, the loss of a parent, as his father took his own life by shooting himself in the head. (Martin 353). Secondly, we see how Hemmingway had had many accidents, such as in 1944, while covering World War II in England, Hemingway was in a car accident on the way home from a party thrown by photographer Robert Capa(Martin 355). Less than three months later, he was in a motorcycle accident as he was invading the German forces in Normandy, the accident left him with slowed speech and memory loss for several months (355). While the two accidents may be waved away as unforeseeable or unintentional, the worst instance that depicts suicidal tendencies is when Hemingway attempted to escape through a plane's door by battering it with his head. He sustained two fierce blows to his head, lacerating his scalp and fracturing his skull, so that cerebrospinal fluid leaked from his ear. The crash left him again with diplopia, temporary deafness, and significant injuries to his liver, spleen, and kidney. (355) 
A major part of PTSD patients apart from the trauma they face, is their flight or fight response or their coping mechanism. For Hemmingway, these mechanisms included drinking excessively, getting involved in dangerous sports and activities such as bullfighting and hunting; and as for Odysseus, we see the coping mechanism in his egocentric attitude that drives him to take on the forces of Gods such as Poseidon, Nymphs such as Circe and Demigods such as Polyphemus.

The results we draw from comparing the two figures, and the instances of trauma and hopelessness, we are able to identify key features of the psyche of Odysseus, and thus bring his relevance to the postmodern times as a man who if existed today, would be idolized as a hero and veteran but would at the same time be viewed as a classical figure that exhibits all the mental trauma that war brings. Through the study of the character, we see how the psychology of our human mind, though its severity was discovered only recently, has had its roots for longer than we can even fathom.

Conclusion

And thus as we apply the definition of trauma by diving deep into the psyche of the Classical Greek Hero Odysseus, and as we run parallels between a figure that existed over 3,000 years ago with that of a postmodern poet Joseph Brodsky and the war veteran Hemmingway, we see that Odysseus is more than relevant in our postmodern times. As we trace the character through the ages, how he has been morphed and used as a means to meet different ends by different writers, we understand that be it the Hero Odysseus, the vile Ulysses, the Modern Subject of Enlightenment, or the postmodern war veteran, he is in the end just a human, with all the troubles and wars that fester incessantly in all our minds, with demons that we harbor that can turn out to be more ferocious than the figures seen in The Odyssey, Aeneid or Inferno. And so, we shall embrace the mythical character of Odysseus as a Postmodern war veteran, a survivor escaping death and above all, who lives on fighting 
SMART MOVES JOURNAL IJELLH e-ISSN: 2582-3574 p-ISSN: 2582-4406 VOL. 8, ISSUE 12, DECEMBER 2020

trauma and the war of the mind that Homer leaves out in his works, a war that begins, as for any veteran, when he has returned home. For the war never ends but is just internalised with a war against one's own self and the mental scars that the trauma of war leaves behind. 


\section{Works Cited}

Adorno, Theodor W., and Max Horkheimer. Dialectic of Enlightenment. Verso, 2016.

Alighieri, Dante, et al. Inferno. Random House ; London, 2003.

American Psychiatric Association. Diagnostic and Statistical Manual of Mental Disorders : DSM-5. 5th ed., American Psychiatric Association, 2013.

Fagles, Robert. Homer: The Odyssey. Penguin, 1999.

Hemmingway, Ernest. A Farewell to Arms. 1st ed. New York, Charles Scribner's Sons, 1929.

Kant, Immanuel, and Mary J. Gregor. Practical Philosophy. Cambridge University Press, 1999.

Martin, Christopher D. "Ernest Hemingway: A Psychological Autopsy of a Suicide." Psychiatry: Interpersonal and Biological Processes, vol. 69, no. 4, Dec. 2006

Niederland, William G. The Problem of the Survivor : Part I, Some Remarks on the Psychiatric Evaluation of Emotional Disorders in Survivors of Nazi Persecution. Vol. 10, Journal of the Hillside Hospital, 1961.

Shay, Jonathan. "Odysseus in America: Combat Trauma and the Trials of Homecoming." Scribner, no. ISBN 0-7432-1156-1 352, 2002.

Sherratt, Y. "Adorno and Horkheimer's Concept of 'Enlightenment."” British Journal for the History of Philosophy, vol. 8, no. 3, Oct. 2000

Virgil, and Robert Fagles. The Aeneid. The Folio Society, 2010.

Brodsky, Joseph. A Part of Speech. Oxford University Press, 1997. 